\title{
School library policy in South Africa: where do we stand?
}

\author{
Sophia le Roux \\ Sophos Information Services, P.O. Box 695, Swellendam, 6740, South Africa \\ sophos@intekom.co.za
}

\begin{abstract}
Received: $2^{\text {nd }}$ September 2002
Revised: $19^{\text {th }}$ October 2002

The absence of national school library policy guidelines is of great concern to the school library profession as this has an adverse effect on the provision of school library services and curriculum reform initiatives in South Africa. The purpose of this article is to present a review of school library policy initiatives since the report of the National Education Policy Investigation (NEPI) up to the present time, and to provide a perspective on the relationship between school library policy development and the provision of school library services and curriculum reform. The implications for the LIS profession are discussed. It is suggested that the LIS profession make a combined effort to form a partnership with educators, other stakeholders and government to engage in school library policy development based on realities on the ground and financial constraints for the benefit of curriculum reform, meaningful school education and a democratic society.
\end{abstract}

\section{Introduction}

There is growing concern among school library professionals about the apparent lack of policy and guidance from the national government regarding school libraries. The absence of national school library policy guidelines is especially a matter of great concern in the light of the release of the Revised National Curriculum Statement Grades R-9 (Schools) by the Department of Education (DoE) in April 2002 (South Africa. Department of Education 2002). The supply of a wide variety of educational resources is a critical component of curriculum planning and implementation (Le Roux 1999:5). It should be regarded as one of the three pillars of curriculum and not be treated as an optional extra (Potenza \& Monokolo 1998: 173, 182).

Knuth (1995:290) believes that effective government policies may push school library development forward, while nonexistent or poorly devised policies may hamper development at every phase from conceptualisation and planning to implementation. School library policy has proved to have a significant effect on school library development worldwide because that development is driven by official recognition inherent in legislation and formal policy statements (Knuth 1995:290). Nevertheless, education policy makers in South Africa continue to ignore the role of school libraries in supporting teaching and learning.

The purpose of this article is to review school library policy initiatives since the report of the National Education Policy Investigation (NEPI) up to the present time and to provide a perspective on the relationship between school library policy development and the provision of school library services and the implications for the LIS profession. The article is organised in four parts: a review of school library policy research and development initiatives before the new education dispensation; an analysis of school library policy documents issued by the new government; an examination of the functional relationship between school library services and Curriculum 2005; and a discussion of the implications of school library policy making (or the lack thereof) for school library services and for the LIS profession in South Africa.

\section{National policy making}

To arrive at a conceptual framework for a critical examination of the status of school library policy in South Africa, the concept, policy, is firstly defined, after which policy making as a process will be explored.

Policy can be defined as:

a definite course or method of action selected from among alternatives and in light of given conditions to guide and determine present and future decision, and also:

a high-level overall plan embracing the general goals and acceptable procedures especially of a governmental body. (Merriam-Webster's 2002)

The policy making process can be defined as both:

... a process in which individuals, groups and/or actors interact on the basis of different views and convictions, with a policy plan as a result.

and also as:

... a process in which an administration, or other actors and/or individuals think about, formulate, communicate and decide on plans to change things in society or in the organization itself. (Speel 1997) 
Levin points out that policy making involves some series of stages moving from the identification of a problem through the identification or adoption of particular strategies, to issues of implementation and impact. He (Levin 200I:3) identifies the following four stages in the education policy making process.

I. Origins. Where did particular policy proposals come from? How did they become part of the government agenda? What role did various stakeholders and interest groups play in the development of the policy?

2. Adoption. How do policies as finally adopted or made into law differ from those originally proposed? What factors lead to changes between proposals and approval? Who supported and proposed various policies, and to what effect?

3. Implementation. What model of implementation, if any, did governments use to implement their policy? What policy instruments (e.g. legislation, regulation, funding, capacity building, professional development, reorganisation and transformation) were used to support policy initiatives. How did schools and school systems respond to the policy guidelines?

4. Outcomes. How have the policy initiatives affected learner outcomes and learning processes in schools?

Levin (200I:5) points to the fact that at every step of policy making, multiple and conflicting influences come to bear, purposes change or are worn down by existing structures and processes, and circumstances alter in ways that require modification of plans and actions. He emphasises that the entire process of policy development and implementation takes place in a short-term context that is constantly changing, multi-faceted, and very difficult to read and is also affected by long-term trends in government and society. Finally, he (Levin 2001:6) points out that most of the time, governments are operating under circumstances that are far from optimal due to pressures of time, lack of information, and multiple competing issues. Knuth (1995:291) is of the opinion that policy-making is a 'social process', reflecting varying systems of values, and that this process is influenced by multiple and complex interests. Lindblom \& Woodhouse (1993) compare policy to 'primeval soup' because of its complex and 'messy' nature, while Ball also alludes to the complexity of national policy making:

National policy making is inevitably a process of bricolage: a matter of borrowing and copying bits and pieces of ideas from elsewhere, drawing upon and amending locally tried and tested approaches, cannibalising theories, research, trends and fashions and not infrequently flailing around for anything at all that looks as though it might work. Most policies are ramshackle, compromise, hit and miss affairs, that are reworked, tinkered with, nuanced and inflected through a complex process of influence, text production, dissemination and, ultimately, re-creation in contexts of practice.

(Ball 1998:126)

In analysing policy matters, Levin believes that one should consider not only the ways in which policies are driven by a particular logic or ideology, but also the ways in which they are shaped by other factors - historical, cultural, institutional, and political (Levin 2001:6). This is particularly the case in South Africa, where school library policy making must be seen within the context of the transformation process which the education system, as well as the library and information services (LIS) sector, have undergone during the recent transition from a racist apartheid-based society to a non-racial democracy.

\section{Policy research and development prior to the new education dispensation}

Report of the NEPI Library and Information Services Research Group

The National Education Policy Investigation (NEPI) was a project of the National Education Co-ordinating Committee (NECC) conducted between December 1990 and August 1992. The aim of this investigation was 'to explore policy options in all areas of education within a value framework derived from the ideals of the broad democratic movement'. The policy options took as their point of departure the NEPI principles of democracy, unity, non-discrimination, and historical redress (National Policy Investigation 1992:3). The twelve sectoral reports were meant to provide an analysis of feasible options for the short- to medium-term future. One of the sectoral reports dealt with policy options for library and information services (LIS).

After providing an overview of school library services during the previous education dispensation, the LIS report observed that there had been an apparent gap between the collective official vision of the role of school libraries in education by the former education authorities and the actualisation of the aims pronounced in official policy. This had resulted in inadequate school library provision. This, according to the report, could be ascribed partly to an absence of physical provision, a lack of materials, a shortage of trained staff and an educational philosophy predominantly discouraging critical thinking, self-directed learning and independent self-study.

The NEPI report stated that: 
The problems stem not only or simply from inequitable distribution of resources, but also from faulty conceptualization of the role of libraries in schools, and a lack of understanding of functional relationships, for example, between the restructuring of a school library service and curricular reform. Education departments do not generally perceive school libraries/media centres to be central to the process of teaching, either as support for teachers or for the use of students

(National Policy Investigation 1992:14)

The report concluded that part of the problem could be ascribed to the way in which the curriculum is structured and also to disparities in the allocation of learning resources. It voiced the opinion that substantial changes could only occur when financial resources would be allocated specifically to the development of learning resources within schools, and teachers would consider the development of learning resources as integral to their philosophy of teaching (National Education Policy Investigation 1992: 14).

It was acknowledged in the report that limited resources by government would result in insufficient funds to redress imbalances in library provision, and it was argued that shared or joint-use services (e.g. between school and public libraries) would be the only way of achieving improved provision. (National Education Policy Investigation 1992:61,68). Resource-sharing and combining the functions of public and school libraries into single administrative units, were seen as possible ways to achieve the optimal utilisation of available physical facilities and materials collections together with improved access to existing services (National Education Policy Investigation 1992:74-75).

In the report it was argued that the integration of school libraries with other educational services would greatly enhance educational opportunities and performance. To improve education, the report anticipated two options by the new government (National Education Policy Investigation 1992:76-77):

- 'continuing to view LIS as auxiliary to education;

- shifting to the approach that LIS are integral to the education process.

The latter approach would require the incorporation of information skills training into the curriculum which would 'help to create a pool of skills that could and would be transferred to environments after and beyond school'(National Education Policy Investigation 1992:77).

Nassimbeni (1994:153) refers to the limited scope of the NEPI investigation as it was only engaged in the first stage of the policy cycle, the clarifying intellectual stage (Levin's origins). The report could therefore not go beyond suggesting policy alternatives to stating preferred policy options. It would, however, appear that the NEPI report placed a high premium on LIS being integral to the education process, and on the teaching of information literacy for increased utilisation of LIS facilities and as a prerequisite for a democratic society.

The NEPI process was, according to Nassembeni (1994:154), beneficial to the library profession in learning about the policy cycle process which would benefit the profession in lobbying government about LIS issues. However, the report was also found to have some deficiencies. Nassembeni (1994:154) points out that some sectors were under-represented in the NEPI process, e.g. people from the rural areas, black women and the school library sector. In addition, she (Nassembeni 1994:154) feels that the meaning and implications of the NEPI principles in the context of library and information services on the ground had been insufficiently debated.

Nassimbeni (1994:153) is also of the opinion that a difficulty inherent in the LIS report was the lack of existing basic research and data on which to build, in contrast to some of the other research areas of the NEPI investigation. However, Lor (1993:15) feels that although the NEPI report contained flaws, such as inaccuracies and sometimes superficial or simplistic conclusions, the report brought the LIS profession closer than ever before to a paradigm shift in library and information work.

African National Congress' Policy Framework for Education and Training In Chapter sixteen of the draft policy document: A Policy Framework for Education and Training (hereafter referred to as ANC Policy Framework), which was published by the Education Department of the African National Congress (ANC) in January 1994, Library and Information Services were addressed. Among the policy proposals put forward in the document, the following are of particular relevance for school library services (African National Congress 1994a:81):

Every education institution will provide its learners with access to an appropriate LIS;

and

Information skills will form part of the national core curriculum in all educational sectors.

Implementation Plan for Education and Training

The Implementation Plan for Education and Training (IPET) by the African National Congress's Education Department attempted to indicate how the ANC Policy Framework would be implemented (and by whom), and under what conditions 
in order to be successful (African National Congress 1994b). Chapter eleven dealt with Library and Information Services (LIS). The IPET confirmed the central role the ANC had assigned to information and libraries in all educational sectors: Information literacy is central to the empowerment of learners. Without libraries and information services, studentcentred and resource-based learning, which liberate students and teachers from authority-centred and textbookbased rote learning, are doomed to failure.

(African National Congress 1994b:208)

With regard to the School Library System (SLS), the term used to refer to arrangements and structures for the provision of school libraries, collections of library materials in schools, and the corresponding infrastructural and administrative support (African National Congress 1994b:234), the report presented an overview of government spending by the different education departments on school libraries (on the item Library Materials) from 1987/1988 to 1991/1992, in order to arrive at projected costs in providing a future SLS. The figures arrived at suggested that instead of percentage increases in expenditure on the provision of library materials in a future SLS, an approach should be followed where the provision of library materials in the previously disadvantaged schools would be gradually improved to bring it on a par with schools in the advantaged communities (African National Congress 1994b:238).

It was estimated that the provision of core collections to schools in the previously disadvantaged schools, at five items per learner over a five year period, would cost R216 49I 452 per annum. If the approach of the Read, Educate and Develop (READ) Educational Trust, a non-governmental organisation active in the provision of school and community library services in underprivileged areas, were to be followed in providing classroom collections to primary schools, through box libraries over a five year period, the amount was estimated to be RI I 424779 . To set up centralised school libraries in secondary school in the previously disadvantaged communities, with ten items per learner, would cost approximately RI49 670000 over five years. These cost estimates did not take into account cost items such as buildings, library rooms, equipment, furniture, infrastructure and staffing (African National Congress 1994b:239).

It was acknowledged in the report that library materials in schools might be under-utilised in the absence of personnel to take responsibility for the material and the operation of the school library and a lack of teacher training to equip class and subject teachers to integrate the resources into the teaching/learning programme (African National Congress 1994b:239). The employment of teacher-librarians was therefore regarded as critical to an effective SLS. The estimated annual cost for the employment of one teacher-librarian and one half-time administrative assistant per five primary schools in the previously disadvantaged areas was estimated to be RI53 279560 (African National Congress 1994b:240) and that of one teacher-librarian and one half-time administrative assistant per secondary school R376 353013 (African National Congress 1994b:24I).

In the light of the above cost estimates, the report presented what was seen as realistic cost estimates for a future SLS for the next five years. These estimates were based on the premise that current school library facilities would be maintained. They also presuppose the following: interim provision of core collections of library material to underresourced schools; the employment of teacher-librarians and accompanying administrative assistants; and the eventual provision of a school library ('resource centre') to every school. For the cost estimates, schools were classified into three categories according to their prevailing levels of provision. For the under-resourced schools, the interim provision of core collections (five items per learner), phased in over a five year period, was seen as a more realistic option than the immediate and more costly establishment of a centralised school library in every school. The costs of the provision of core collections to these schools were estimated to be R216 49I 452 (African National Congress 1994b:244). The employment of library personnel for these schools was considered to be a necessary parallel development (African National Congress 1994b:243).

As it was acknowledged that this figure would be unrealistic in terms of the total education budget, it was proposed that, instead, one item per learner in under-resourced schools would be purchased every three years, bringing the total to R72 163817 per annum. This, together with maintenance of the school library stock of the well-resourced schools, would bring the total annual budget for library material of all schools to R86 894297 per annum over a period of five years. The ideal situation envisaged by the report was that, in ten years time (2004), each school would have ten items per learners and that each school would have the services of library personnel, whether shared or dedicated (African National Congress 1994b:244).

\section{Current government policy development}

Legislative framework for rendering school library services

Policy on the provision of school library services is prescribed by legislation, i.e. the Constitution and various other Acts. Schedule 5A of the Constitution states that 'libraries other than national libraries', are a provincial responsibility (South Africa 1996: 1 19). Two Acts have a bearing on the rendering of school library services. The National Education Policy Act, 
1996 (Act No. 27 of 1996) empowers and authorises the Minister, through the Department of Education, to develop national policy that will improve the provision of facilities that contribute towards quality education. This is understood to include the provision of library facilities in schools. The implementation of standards for school libraries is, however, a provincial matter. Both the national and provincial departments of education should therefore co-ordinate their efforts in making improvements in the provision of school library services (National Committee for Library Co-operation 2000:20).

Although school libraries are not mentioned specifically in the South African Schools Act, 1996 (Act No. 84 of 1996), this Act impacts on the delivery of school library services as a result of the functions assigned to school governing bodies (SGBs). Section 36 of the Act imposes a responsibility on all SGBs of public schools to do their utmost to improve the quality of education in their schools by raising additional resources to supplement those which the state provides from public funds. This implies budgeting for any school library model that, according to the SGB and the school, would be the most suitable one for their local needs (National Committee for Library Co-operation 2000:21).

A National Policy Framework for School Library Standards

After a long consultative process involving school library stakeholders across the country, the Centre for Educational Technology and Distance Education (CETDE) of the Department of Education (DoE), in 1999, published its draft policy document: A National Policy Framework for School Library Standards. This policy document was the result of the cooperation between the CETDE, a Research Working Group and all the provincial senior managers of school library services, incorporating inputs of several experts on school library services (South Africa. Department of Education 1999:iii).

In the document it was stated that this was the first policy document of the department which regarded school libraries as integral to the curriculum in South Africa. It was argued that teachers and learners would only be able to access an outcomes-based curriculum if they had access to learning resources (South Africa. Department of Education 1999:iv). The draft policy document acknowledged that the majority of public schools in South Africa do not have functional school libraries and that provincial education departments (PEDs) do not have the finances or the personnel at their disposal to ensure immediate closing of the gap between schools and so attain equal levels of library service in every school. In addition, it was realised that no school library would ever be able to satisfy educators' and learners' complete resource needs in accessing the new curriculum (South Africa. Department of Education 1999: I I).

Taking those realities into account, the draft policy document suggested different models of school libraries from which each school could choose, according to its own particular circumstances (South Africa. Department of Education 1999:iv). It was recommended that PEDs follow a transitional approach in the provision of school libraries by allowing school communities to choose from a 'menu' of seven school library models, thus establishing temporary or transitional alternatives to the traditional centralised school library (South Africa. Department of Education 1999:13).

This position taken in the policy document was based on the view that a school library could comprise various models and, in fact, should be seen as a teaching method to enhance the school's curriculum and not just as a physical facility (South Africa. Department of Education 1999:5). This point of view constituted a complete departure from the established view of the centralised school library as being the only model of school library available to school communities. The document stated:

... it is no longer tenable to claim that there is a 'model library' and a 'right' way of providing educators and learners

with learning resources.

(South Africa. Department of Education 1999:6)

The policy document therefore uses the name school library as a generic term, incorporating all forms and models of collection development and delivery (South Africa. Department of Education 1999:5). The school library collection is primarily seen as the vehicle for the acquisition of information skills by the learners for lifelong development (South Africa. Department of Education 1999:7). Additional benefits of this flexible approach to the provision of school libraries are apparent in the fact that school libraries are less dependent on the state and also in the establishment of partnerships between interest groups and private enterprises and the schools (South Africa. Department of Education 1999:12).

A Four Year Implementation Plan

During January 2000, the draft policy document with the title: A Four Year Implementation Plan of the Policy Framework for School Library Standards was released by the CETDE (hereafter referred to as Implementation Plan). The purpose of this Implementation Plan was to chart the strategic direction and describe the activities that were planned in pursuit of the draft policy document: A National Policy Framework for School Library Standards (hereafter referred to as Policy Framework). The Implementation Plan was developed jointly and with the participation of education managers from national and provincial departments of education represented on the Standing Committee of Heads of Education Library and Information Services (SCHELIS) (South Africa. Department of Education 2000:6). 
In the Implementation Plan, six key strategies were described as emerging from the Policy Framework and its recommendations (South Africa. Department of Education 2000: I I- I3).

I.A range of seven library-based resource models for schools is suggested.

2.A set of twelve generic standards is given for each school.

3.School managers and the School Governing Bodies are encouraged to follow a transitional approach in developing a school library for their school, by adopting one of the provincially approved library models for the particular school, by taking the current local infrastructure, social context, educational needs and resources of the school into consideration.

4. The effective utilisation and the integration of the collection of learning resources into class activities is actively promoted.

5.The supportive role of the DoE through the CETDE is affirmed.

6.The DoE will be engaged in the process of educator development.

To advance each strategy, several goals or outcomes were identified with one or more action plans being developed from these goals. Action plans included capacity building of media advisors to support and monitor the implementation of the various school library models, and the development and supply of core collections of learning materials to new and rehabilitated schools as a first stage in the development of a school library (South Africa. Department of Education 2000: 17). The time scale for achieving the outcomes was set from 2000-2003. The total costs of the Implementation Plan were estimated to be R34 209500.00 (South Africa. Department of Education 2000:21). In its conclusion the Implementation Plan stated:

Indeed, we believe that the Implementation Plan of the Policy Framework for School Library Standards will prove to be the historic turning point in this government's provision of learning support materials for South Africa's most disadvantaged learners and their teachers.

(South Africa. Department of Education 2000:22)

Draft Policy on South African School Library Services

During December 200I, the DoE unexpectedly released a new draft policy document on school library services for comment. This document, the Policy on South African School Library Services (South Africa. Department of Education 2001 :4) claimed that its mandate could be found in the White Paper on Education and Training which points out that:

... the state has an obligation to provide the basic physical facilities and equipment to all state schools. ... It should include access to classrooms of an agreed standard at an agreed ratio, the provision of basic services and infrastructure such as water, toilets and electricity, and an administration block, as well as educationally necessary facilities such as a library, laboratories and workshops where appropriate, and recreational facilities.

(South Africa. Department of Education 1995:77)

The premise of this new policy document is that, according to the White Paper, the provision of a library to every public school and college is the responsibility of the state. However, the policy document does not acknowledge the fact that this 'responsibility of the state' has not been affirmed in the South African Schools Act, 1996.

The draft Policy on South African School Library Services briefly describes the various school library models suggested in the draft policy document: A National Policy Framework for School Library Standards. It then states:

The Policy on South African School Library Services underscores the One School One Library Model (own emphasis). Every school should have its own library to serve its learners. ... Because the remaining models make provision for sharing amongst schools, they are not acceptable.

(own emphasis )

The draft policy document then presents some minimum standards for libraries in South African schools with regard to the facility, stock, staffing, institutional support by the DoE, the PEDs and the schools themselves, and additional resourcing (South Africa. Department of Education 2001:6-9).

\section{School Library Services and Curriculum 2005}

With the promulgation in October 1997 by the Minister of Education of Curriculum 2005 (C2005) as the new outcomesbased curriculum for General Education and Training, expectations ran high that learning resources and libraries would take a central place in the curriculum. School library professionals were adament in their view that, especially in the previously disadvantaged schools, C2005 could not succeed without the necessary learning resources together with the development of educators and learners in using them effectively. This view was shared by many educators:

What is at stake here is that learning materials are a critical part of curriculum implementation. This is particularly the case in contexts such as ours in which there is a severe shortage of basic educational resources in the majority of 
schools and where many teachers lack the basic skills required to teach effectively.

(Potenza \& Monokolo 1998:182).

Potenza \& Monokolo however, observed that the provision of learning resources and educator development to use these resources effectively in their class practice had not been taken into account in planning for the new curriculum:

... the critical factor in successfully translating Curriculum 2005 into practice is to ensure that the three pillars of curriculum transformation are in place, and in alignment. These pillars are curriculum development, teacher development and the development, selection and supply of learning materials. As implementation of Curriculum 2005 begins, there are apparently no clear strategies to put these pillars in place in any province.

(Potenza \& Monokolo 1998: 182)

The report of the President's Education Initiative (PEI) Research Project, Getting learning right (Getting ... I 999), reporting on the assessment of the implementation of Curriculum 2005 in the schools, affirmed that the lack of learning resources in the previously disadvantaged schools has a detriment effect on the reading and cognitive skills of the learners in these schools. In addition, the report stated:

The PEI research studies found that very few teachers are using textbooks in their classes in any systematic way. This was even the case when textbooks were available at schools. The researchers suggest that teachers avoid using textbooks because they do not have the content knowledge or reading skills to use these books.

(Getting ... 1999:183)

Lor, in his Memorandum on the State of Libraries in South Africa, March 1998, presented to the Portfolio Committee on Arts, Culture and Languages, Science and Technology on 23 March 1998, also voiced his concern about the lack of learning resources and the deterioration of school libraries:

The introduction of Curriculum 2005, which emphasises resource-based and learner-centred learning, makes students more dependent than ever before on school libraries and media centres. The deterioration of school libraries and media centres poses a grave threat to the success of Curriculum 2005.

(Lor 1998:8)

When Curriculum 2005 and its implementation were reviewed by a Ministerial Committee in 2000, under the chairmanship of Professor Linda Chisholm, it was hoped that school libraries and learning support materials (LSMs) would at long last be placed on the agenda. However, there was no explicit mention made of the potential role of school libraries and librarians in curriculum transformation and support in the Review Committee's report, and in the report the focus was solely on the quality of textbooks and on the curriculum support materials produced by the Department of Education with the implementation of C2005 (Report ... 2000, Chapter 5:I).

The report admitted that, contrary to government policy (with the implementation of C2005), the training offered by both national and provincial education departments from 1997-1999 had reinforced the controversial view that teachers and learners had no need for textbooks. It was affirmed in the report, that in order to be an 'interpreter and designer of learning programmes and materials', as required by $C 2005$, teachers need to have access to substantial resource materials (Report ... 2000, Chapter 5:5).

The report also pointed out that generally there was little use of learning materials and acknowledged that the use of learning materials needed to be mediated:

... supplying adequate amounts of textbooks is not enough in itself. Such supply has to be accompanied by professional development that enables teachers to understand the pedagogical approaches underpinning the textbooks they use. ... Evidence from site visits has shown that there are cases where teachers do not use textbooks even when they are available.

(Report ... 2000, Chapter 5:6).

The report, therefore, recommended that teachers should be trained in the use of LSMs, and especially textbooks (Report ... 2000, Chapter I). No mention is, however, made of the potential role of teacher-librarians in this regard.

One of the problems identified in the report as affecting the availability of LSMs in schools is the lack of clear budget planning for the funding of LSMs (Report ... 2000, Chapter 5:7). Some of the recommendations of the report are as follows: the implementation of ring-fenced budgeting for curriculum and LSMs; the separation of the budgets for stationery and textbooks; the establishment of a recommended list compiled by an advisory panel for each learning area; a movement away from the existing tender procedures in book acquisition by schools; and the creation in each province of a special project team to co-ordinate and manage LSMs (Report ... 2000, Chapter I).

In his press statement on the release of the Draft Revised National Curriculum Statement for Grades R-9 (Schools), the Minister of Education (Asmal 200I, Chapter 5:2) admitted that:

The adequate and timeous supply of quality learning support materials is critical to the successful implementation of the revised National Curriculum Statement. 
He (Asmal 200I, Chapter 5:2), therefore, promised:

A dedicated budget line item will ensure regular supply of learning support materials to classrooms.

Other key areas of policy that were identified and which would be attended to included the management of LSMs at the school level and the professional development of teachers focusing on the development and use of LSMs (Asmal 200I, Chapter 5:3).

\section{Implications for the LIS profession}

From the analysis of school library policy initiatives by the Department of Education since the inception of the new education dispensation, it is clear that the policy making process has not gone beyond the first stage of development, namely that of Levin's origins. In answering the questions: 'Where did particular proposals come from?', and 'How did they become part of the government agenda?', and 'What role did stakeholders play in the development of the policy?', there is incontrovertible proof that, since NEPI, the school library profession, and even the broader LIS profession have been engaged in an ongoing process of consultation, communication and lobbying efforts to place school libraries on the national agenda in the light of curriculum reform by the Department of Education.

In particular, the draft policy document: A National Policy Framework for School library Standards has gone through a protracted consultation process. Consequently, this document reflects the collective view of the school library profession. It is, therefore, regrettable that this well-researched document, which is based on the reality of exisiting school library services delivery in South Africa, has been replaced by the draft Policy on South African School Library Services (hereafter referred to as The Policy), which appears to be a vague, unrealistic and poorly-researched document. The Policy does not meet the requirements of 'a definite course of action ... to guide and determine present and future decision', as defined earlier in this article. Expressions in The Policy such as: '... Because the remaining [school library] models make provision for sharing amongst schools, they are not acceptable', appear to have an ideological basis and militate against the principle of resource-sharing accepted by the LIS profession worldwide. They do also not consider the economic realities facing PEDs. The rationale behind the introduction of a 'menu' of school library models in the Policy Framework was precisely to try to diminish the backlogs in the previously disadvantaged schools:

The incremental approach [in slowly increasing the number of schools with centralised traditional libraries] entails an uncompromising approach where the education department provides a centralised library for each school. This process could only be implemented gradually as it will take provincial departments many years - if not decades before there is full provision of libraries in the light of the present backlog of schools without libraries. This might widen the gap between privileged and disadvantaged schools even more.

(South Africa. Department of Education 1999:II).

With regard to the sharing of resources and services, The NEPI report noted:

One of the implications of this approach [radical approach] is that equality of service, a long-term goal, might not be achieved in the short term, because resources would be focused on disadvantaged groups. The reality of limited resources means that insufficient funds would be available to redress imbalances in any meaningful way. As a result, shared or joint-use services would be the only way of achieving improved provision.

(National Education Policy Investigation 1992:68)

The Policy appears to resort to the old view of the school library as a 'place' and not as a 'teaching method' being a catalyst for educational change (Le Roux 1999:3). References to the minimum standard of this place as being 'big enough to display library books on shelves' (South Africa. Department of Education 2001:6) are meaningless and ambiguous, and it is questionable whether such a 'place' could 'create space for learning experiences suitable to learners' abilities and interests' (South Africa. Department of Education 2001:7).

The minimum standard of twelve library items per learner, as proposed in The Policy, appears to be quite unrealistic in the light of the findings regarding book stock in school libraries contained in the South African School Library Survey 1999 report (South Africa. Department of Education \& Human Sciences Research Council [2000]), which to date has not been officially released by the Department of Education. No indication is given in The Policy as to how the Department of Education plans to achieve this goal. In the light of previous documents, such as the ANC's Implementation Plan for Education and Training, one also doubts whether this figure (twelve items per learner) has been costed and whether the provincial education departments will be able to "provide each public school with funds to enable them to meet the minimum requirements ...' (South Africa. Department of Education 200I:8).

In order to move to the next stage of policy making, namely Levin's adoption, The Policy has to become an approved piece of legislation, regulation, or policy. That means that the document must be transformed into something which has to be worked out into detail in order to manage large-scale changes (Levin 200 I:8). It appears that The Policy has so many shortcomings that patchwork simply will not do. The document has to be completely reworked and should be based on 
the realities of current school library provision and financial constraints. It 'needs continuous interaction between vision and conditions on the ground' (Christie 1999:290). Only then will it have a chance to be approved by senior management of the Department of Education, the Heads of Departments of Education Committee (HEDCOM) and the Minister of Education.

Knuth (1995:290) believes that concerned school library supporters may intervene more effectively in policy formulation and implementation if they have a basic knowledge of the limitations and complexities of policy and the process of policy-making. Education policy in itself has its limitations and seldom changes classroom practice (Christie 1999:287). Christie (1999:282) points out that the sophistication of policies (such as OBE and C2005) brings the unintended effect that they are likely to be of most benefit to those communities and schools that have the resources to take advantage of the opportunities they offer. '[With the implementation of OBE] ... a curriculum regime that presupposes a resource-rich learning environment was imposed on poorly resourced schools, which were expected to respond "innovatively"' (Dick 200 I:45). In that way policy, in fact, creates inequality. This would also be the case with the sharing of resources between already poorly-resourced schools and community libraries. Therefore, in the rural, tribal areas, appropriate models of school libraries should be considered offering a service to the whole community, such as multi-purpose community centres (Dick 200 I:46; Le Roux 200I).

Policy could, however, be an instrument in leveraging changes in school library service delivery, provided it is accompanied by the necessary funding and the key points of leverage are identified to bring about the desired change. This is especially the case in the areas of organisation and management and in institutional capacity, as well as in giving directions to schools how to act (Christie 1999:287-288). Besides, according to Knuth (1995:292), school library provision that is not supported by national policy becomes vulnerable to financial cuts and local education politics (Knuth 1995:292).

The issue of school library policy, however, requires the undivided attention of the whole library profession, as the access to a variety of information resources lies at the heart of C2005, meaningful school education and a democratic society. The school library policy initiative should, however, embrace all stakeholders, such as educators, nongovernmental education organisations, teachers' unions, publishers and decision-makers in all three spheres of government. In its first report to G8 leaders, the Digital Opportunities Task (DOT) Force stressed (Digital Opportunity Task Force ... 2002:2):

access to knowledge and information is a prerequisite for modern human development.

In order to play a meaningful role in the debate around the provision and use of learning resources, the LIS profession should have a clear vision of the desired outcomes that school library services would yield. The focus should be on knowledge acquisition with information at the core and access for all learners at all times. This would require reaching higher than, and stretching past, the four walls of the school (Smith 2002:2). Ross Todd as quoted by Hartzell argues in this regard:

We can understand libraries better ... if we think of them as knowledge spaces rather than information places and if we emphasize the connections they offer rather than the collections they hold.

(Hartzell 2002:7)

The role of the teacher-librarian, i.e. the staff member responsible for the school library, should also be clearly defined in the light of financial constraints imposed on PEDs by the National Norms and Standards for School Funding (South Africa. Department of Education 1998:5) with respect to personnel expenditure. Teacher-librarians can, however, play an important role in encouraging a love of reading and in inculcating the values of 'taste, discrimination and evaluation' during the reading process (Dick 200I:43), not only in schools but also in the broader community:

The teaching/learning process must be emphasized through the model of a teaching library. Librarians must be viewed and behave as teachers - of teachers, of students, and the community. ... A basic foundation of the school must be that information literacy has to be incorporated throughout the entire program. ... A commitment to information literacy must permeate the culture of the school.

(Smith 2002:4,5)

The LIS profession should make it very clear to government that the provision of school libraries is not synonymous with computerising and networking schools. In a developing country such as South Africa, printed media will for a long time take precedence over electronic resources. Although initiatives in schools, such as the GautengOnline pilot programme (Sefin Marketing 2002:I) and the Western Cape's Khanya project (Rekenaarplan ... 2002), are to be commended, the Internet cannot replace a good efficiently functioning school library service. According to the Department of Education of asmania,

The Internet just provides access to hundreds of thousands of places to find data. It does not determine which of these places provides the best, most authoritative, most correct information, nor does it filter wheat from chaff. 
That's what the librarians do.

(Tasmania 2002:2)

The LIS profession needs to lobby their case more aggressively, but its arguments have to be based on the realities of current school library services provision as illustrated in the South African School Library Survey 1999 report, and also on the resources available to the provincial education departments. Vermeulen and Stander, as quoted by Karlsson \& Nassimben (1996:19), suggest that a useful approach would be to assess the mission, aims and objectives of the school library in relation to curriculum delivery as the basis on which to determine the nature, size and scope of the facilities and services. A flexible approach is needed taking account of conditions on the ground. In a presentation to members of the Council of Federal Libraries, Canada, in 1996, Art Parker (1996) suggested a particular approach in lobbying for library services. An adapted version of this approach could be used by the LIS profession in South Africa to show politicians and administrators the value of school library services for school education.

- Align the processes, services and goals of school libraries more closely with the goals of teaching and learning.

- Talk to education policy-makers, administrators and educators in terms they understand, not in library jargon.

- Put concern for departmental needs and broader political issues before professional standards.

- Strengthen your marketing skills.

\section{Conclusion}

This article attempts to scrutinise school library policy making in South Africa from the NEPI report up to the present time. It is found that the policy making process has not gone beyond the first stage of development, i.e. that of its conception. This process has never progressed to the adoption, implementation and evaluation stage. This has been to the detriment of school library services and school education. It is argued that there appears to be an inability on the part of the school library profession to enter into a fruitful partnership with educators, other stakeholders and government aimed at joint development of school library policy guidelines which are based on the realities of current school library service delivery on the ground and available provincial and local resources. In order to ensure that much needed policy guidelines for school library services are developed, assigning a clear-cut place for these institutions within the school system, it is suggested that the LIS profession should make a combined effort to lobby stakeholders groups and government on this issue, while reconciling divergent interests and goals.

\section{References}

African National Congress. Education Department. 1994a. A policy framework for education and training. Braamfontein: ANC Education Department.

African National Congress. Education Department. 1994b. Implementation plan for education and training. [Braamfontein]: Department of Education, ANC.

Asmal, K. 200I. Statement by prof. Kader Asmal, on the release for public comment of the draft revised national curriculum statement. Pretoria: Department of Education.

Ball, S. 1998. Big policies/small world: an introduction to international perspectives in education policy. Comparative education, 34(2): 126.

Christie, P. 1999. OBE and unfolding policy trajectories: lessons to be learned. In Jansen, J. \& Christie, P. eds. Changing curriculum: studies on outcomes-based education in South Africa. Kenwyn: Juta.

Dick, A.L. 200I. Reading and outcomes-based education: should income be the key outcome? Perspectives in education, 19(2): 37-48.

Digital Opportunity Task Force. 2002. Digital opportunities for all. [Online], 27 June 2002. Available: http://www.dotforce.org/reports/

Getting learning right: report of the President's Education Initiative Research Project. Taylor, N. \& Vinjevold, P. eds. I999. Johannesburg: Joint Education Trust.

Hartzell, G. 2002. What's it take? Paper presented at the White House Conference on School Libraries. [Online], 24 June 2002. Available: $h$ ttp://imls.gov/pubs/whitehouse0602/garyhartzell.htm

Karlsson, J., Nassimbeni, M. \& Karelse, C.-M. 1996. Identifying the inherited problems in the provision of resources for school learners. In Karlsson J. ed. School learners \& libraries. Dalbridge: Education Policy Unit, University of Natal:5-24.

Knuth, R. 1995. School librarianship and macro-level policy issues: international perspectives. IFLA journal, 21 (4):290-298.

Le Roux, S. 1999. Building a nation of readers ... together: public library - school library cooperation. Paper read at the UNESCO Consultation Workshop on LIS Functions in South Africa, Pretoria, 24 November, 1999. (Unpublished)

Le Roux, S. 200I. School-community libraries: some guidelines for a possible model for South Africa. Dissertation submitted in fulfilment of the requirements for the degree of Master of Library and Information Science, Faculty Human Sciences, University of Pretoria, Pretoria. (Unpublished)

Levin, B. 200I. Conceptualizing the process of education reform from an international perspective. Education policy analysis archives, 9(14). [Online], 19 April 2002. Available: http://epaa.asu.edu/epaa/v9n/4.html

Lindblom, C.E. \& Woodhouse, E.J. 1993. The policy-making process. Englewood Cliffs, N. J.: Prentice Hall.

Lor, P. 1993. Africanisation of South African libraries: a response to some recent literature. Unpublished paper delivered at the Africa Nova Conference, Pretoria, May 1993.

Lor, P.J. 1998. Memorandum on the state of libraries in South Africa, March 1998. The LIASA letter, 2(I):7-I2. 
Merriam-Webster's collegiate dictionary. 2002. [Online], 19 Apr. 2002. Available: http://www.m-w.com/cgi-bin/ dictionary?book = Dictionary\&va=policy

Nassimbeni, M. 1994. Constructing national library and information policy options for South Africa within the framework of educational transformation. Journal of librarianship and information science, 26(3): I49-155.

National Committee for Library Co-operation. 2000. National guidelines for co-operation between community and school libraries. Pretoria: UNESCO Pretoria Office.

National Education Policy Investigation. 1992. Library \& information services: report of the Nepi Library and Information Services Research Group. Cape Town: Oxford University Press/NECC.

Parker, A. Demonstrating the value of libraries. 1996. Adapted summary of presentation to CFL members on April 2, 1996 at the National Library of Canada. [Online], 28 June 2002. Available: http://collection.nlc-bnc.ca/I00/20I/30I/liaison-e/liaison-eh/I996-98/ value.htm

Potenza, E. \& Monokolo, M. 1998. A destination without a map: premature implementation of Curriculum 2005? In Outcomes-based education: perspectives, policy, practice and possibilities; compiled by University of Durban-Westville. Centre for Educational Research, Evaluation \& Policy. Durban: CEREP.

Rekenaarplan bring lig vir plaaskinders. Die Burger, 2 I March 2002.

Report of the Curriculum 2005 Review Committee (Prof. Linda Chisholm). 2000. Pretoria: Department of Education.

Sefin Marketing. 2002. E-learning. [Online], 28 June 2002. Available: http://allafrica.com/stories/printable/200206/90468.html

Smith, K.D. 2002. Building student learning through school libraries. Paper presented at the White House Conference on School Libraries. [Online], 24 June 2002. Available: http://www.imls.gov/pubs/whitehouse0602/kathleensmith.htm

South Africa. 1996. Constitution of the Republic of South Africa. [ Act No. 108, 1996]. Government gazette, 18 December 1996.

South Africa. Department of Education. 1995. White Paper on education and training. Pretoria: The Department.

South Africa. Department of Education. 1998. National norms and standards for school funding in terms of the South African Schools Act, 1996 (Act No. 84, 1996). [Online] Available: http://www.polity.org.za/govdocs/policy/norms\&standards.html.

South Africa. Department of Education. Centre for Educational Technology and Distance Education. 1999. A National policy framework for school library standards. Pretoria: The Centre. (Unpublished draft document).

South Africa. Department of Education. National Centre for Educational Technology and Distance Education. 2000. A Four year implementation plan of the policy framework for school library standards. (Unpublished draft document).

South Africa. Department of Education. 200I. Policy on South African school library services. [Pretoria]: The Department. (Unpublished draft document).

South Africa. Department of Education. 2002. Revised national curriculum grades R-9 (schools). Pretoria: The Department.

South Africa. Department of Education \& Human Sciences Research Council. [2000]. South African school library survey 1999: national report. Pretoria: The Department. (Final draft).

Speel, H-C. 1997. A memetic analysis of policy making. Journal of memetics - evolutionary models of information transmission, I. [Online], I4 May 2002. Available: http://jom-emit.cfpm.org/I997/voll/speel_h-c.html

Tasmania. Department of Education. Library and Information Centre, SLT. 2002. "Why do we need a teacher librarian or a school library when we have the Internet?" [Online], 28 June 2002. Available: http://www.education.tas.gov.au/0278/issue/02 I/whytl.htm. 